\title{
Teknik Pelukisan Analitik dan Dramatik pada Tokoh Utama dalam Novel Kembara Rindu Karya Habiburrahman El Shirazy
}

\author{
Novia Isfa Devi \\ Pendidikan Bahasa dan Sastra Indonesia Universitas Muhammadiyah Jember \\ noviaisfadevi99@gmail.com
}

DOI: https://doi.org/10.32528/bb.v6i1.4157

First received: 17-01-2021 Final proof received: 01-03-2021

\begin{abstract}
ABSTRAK
Penelitian ini bertujuan untuk mendeskripsikan pelukisan tokoh yang digunakan penulis untuk menggambarkan watak tokoh dengan teknik analitik dan dramatik pada Novel Kembara Rindu karya Habiburrahman El Shirazy. Pelukisan tokoh merupakan cara yang digunakan oleh pengarang untuk menyampaikan penggambaran watak tokoh. Penggambaran tokoh disampaikan dengan teknik analitik yakni teknik penggambaran tokoh secara langsung oleh penulis dan teknik dramatik yakni teknik penggambaran tokoh secara tidak langsung. Metode yang digunakan dalam penelitian ini adalah metode penelitian deskriptif kualitatif. Data yang digunakan dalam penelitian ini adalah teks yang memuat penokohan dengan teknik analitik dan dramatik pada novel Kembara Rindu karya Habiburrahman El Shirazy. Sumber data pada penelitian ini adalah Novel Kembara Rindu karya Habiburrahman El Shirazy yang diterbitkan oleh Republika Penerbit pada tahun 2019 dengan 266 halaman. Teknik yang digunakan untuk mengumpulkan data ialah teknik telaah dokumen. Hasil dari penelitian ini adalah pada Novel Kembara Rindu penulis menggunakan dua teknik dalam menggambarkan watak tokoh yakni dengan teknik analitik dan teknik dramatik. Berdasarkan penelitian ditemukan bahwa dalam novel Kembara Rindu penulis dominan menggunakan teknik dramatik untuk menggambarkan watak tokoh utama yakni Ridho. Maka, berdasarkan temuan ini menunjukkan bahwa penulis tidak intens menggunakan teknik analitik agar pembaca merasa penasaran dan bertanya-tanya dalam interpretasinya terhadap watak tokoh dalam novel. Teknik analitik yang menggambarkan watak tokoh oleh pengarang secara langsung, menunjukkan watak Ridho yakni ramah, selanjutnya teknik dramatik menunjukkan bahwa tokoh Ridho merupakan orang yang patuh, dapat diandalkan, dapat dipercaya, ramah, sopan, penurut, beretika, bijaksana, cekatan, tegas, pantang menyerah, dan pekerja keras dengan menggambarkannya melalui perilaku tokoh, ucapan tokoh kepada orang lain, ucapan orang lain kepada tokoh, dan cara berpikir tokoh.Abstrak ditulis dalam Times New Roman (12 pt, 1,0 spasi paragraf) dan harus berisi informasi yang diperlukan mengenai manuskrip. Itu harus dimulai dengan maksud / tujuan penelitian, diikuti dengan ringkasan metode, hasil, dan implikasinya. Ini harus 200- 300 kata
\end{abstract}


. Hindari mencurahkan terlalu banyak ruang untuk pendahuluan atau latar belakang, yang tidak perlu.

\title{
Kata Kunci : teknik pelukisan tokoh; analitik; dramatik
}

\begin{abstract}
This study aims to describe the character depictions used by the writer to describe the character's character with analytical and dramatic techniques in Habiburrahman El Shirazy's novel Kembara Rindu. Character depiction is a method used by the author to convey the depiction of the character's character. The depiction of characters is conveyed using analytical techniques, namely the technique of depicting characters directly by the writer and dramatic techniques, namely the technique of depicting characters indirectly. The method used in this research is des (Arikunto, 2006)criptive qualitative research method. The data used in this study is a text that contains characterizations with analytical and dramatic techniques in the novel Kembara Rindu by Habiburrahman El Shirazy. The data source in this study is the Novel Kembara Rindu by Habiburrahman El Shirazy, published by Republika Publisher in 2019 with 266 pages. The technique used to collect data is the document review technique. The result of this research is that in Kembara Rindu Novel, the writer uses two techniques in describing the character of the characters, namely analytical techniques and dramatic techniques. Based on the research, it was found that in the novel Kembara Rindu, the dominant writer used dramatic techniques to describe the character of the main character, Ridho. So, based on these findings, it shows that the author does not intensively use analytic techniques so that readers feel curious and questioning in their interpretation of the character of the characters in the novel. Analytical techniques that describe the character's character directly by the author, only two data are found, namely those that show Ridho's character, namely friendly and trustworthy, then dramatic techniques show that Ridho's character is obedient, reliable, trustworthy, friendly, polite, obedient, ethical, wise, nimble, assertive, unyielding, and hardworking by describing it through the character's behavior, the character's speech to others, what other people say to the character, and the character's way of thinking.
\end{abstract}

Keywords: character painting technique; analytic; dramatic

\section{PENDAHULUAN}

Novel merupakan salah satu karya sastra yang menceritakan tentang realitas kehidupan manusia yang bercirikan adanya konflik-konflik yang akhirnya menimbulkan perubahan yakni keberhasilan atau pun kegagalan yang akan dialami oleh seorang tokoh (Zulfahnur, 2007: 6.10). Menurut Nurgiyantoro (2010: 22) novel merupakan sebuah totalitas, suatu kemenyeluruhan yang bersifat artistik. Sebagai sebuah totalitas, novel memiliki bagian-bagian, unsur-unsur yang saling berkaitan satu dengan yang lain secara erat dan saling menguntungkan. Oleh karena itu, novel dapat dikatakan sebagai suatu totalitas dan menjadi suatu rangkaian cerita yang berwujud karena adanya unsur pembangun novel yakni unsur intrinsik (unsur yang membangun dan ada dalam karya itu sendiri) dan unsur ekstrinsik (unsur pembangun yang berada di luar karya itu 
sendiri).Suprihadi (2009: 37) dalam bukunya mengatakan bahwa novel ialah suatu karangan prosa yang panjang dan mengandung rangkaian cerita kehidupan seseorang dengan orang-orang disekitarnya dengan lebih menonjolkan kepada watak dan sikap yang dimiliki oleh setiap pelaku. Berdasarkan pendapat beberapa tokoh dapat disimpulkan bahwa novel merupakan karya sastra yang dapat menunjukkan suatu realitas sosial yang erat kaitannya dengan segala hal yang berkaitan dengan tokoh yakni peristiwa-peristiwa atau pun konflik yang dialami tokoh dalam suatu rangkaian cerita.

Tokoh merupakan unsur pembangun cerita yang ada dalam struktur narasi cerita dan memiliki peran yang sangatlah penting. Tokoh merupakan personal atau pelaku dalam cerita rekaan yang akan mengalami berbagai macam peristiwa dan konflik pada suatu alur cerita. Menurut Abrams (dalam Nurgiyantoro, 2010: 165) tokoh cerita merupakan orang-orang yang ditampilkan dalam suatu karya sastra naratif atau drama yang diinterpretasikan oleh pembaca sebagai orang yang memiliki kualitas moral dan kecenderungan tertentu yang diekspresikan melalui ucapan dan tindakan yang dilakukan. Tokoh berperan sebagai sarana pembawa pesan atau amanat pengarang terhadap pembaca melalui personalitas atau karakter yang dimilikinya seperti halnya realitas manusia pada umumnya. Tokoh dalam karya rekaan selalu mempunyai sifat, sikap, tingkah laku, dan watak teretntu. Pemberian watak pada tokoh dalam suatu karya sastra oleh sastrawan disebut dengan perwatakan (Siswanto, 2013: 129)

Karakterisasi atau characterization (Bahasa Inggris) memiliki arti pemeranan atau pelukisan watak. Metode karakterisasi dalam suatu telaah karya sastra merupakan metode melukiskan watak para tokoh yang terdapat dalam suatu karya fiksi (Minderop, 2005: 2). Metode karakterisasi biasa dikenal sebagai penokohan. Menurut Tarigan (2008:147) penokohan atau karakterisasi merupakan suatu proses yang digunakan oleh seorang pengarang untuk dapat menciptakan tokoh-tokoh fiksinya. Tokoh fiksi harus dipandang sebagai seorang yang berada pada suatu masa, pada tempat tertentu, dan harus diberikan motif-motif masuk akal sebagai apa yang dilakukannya. Oleh karena itu, tugas pengarang ialah membuat tokoh tersebut menjadi sebaik mungkin, seperti yang sebenar-benarnya ada.

Pada suatu rangkaian cerita tokoh terbagi menjadi beberapa jenis yakni tokoh utama dan tokoh tambahan. Tokoh utama merupakan tokoh yang mengambil sebagian besar peristiwa yang ada dalam suatu cerita. Tokoh bawahan atau tambahan merupakan tokoh cerita yang kehadirannya dalam suatu cerita hanya sebagai pelengkap (Zulfahnur, 2007: 6.30). Langkah yang dapat dilakukan untuk menentukan tokoh utama ialah dengan menemukan tokoh yang paling banyak mendapat peranan atau paling sering muncul dalam peristiwa-peristiwa yang ada dalam cerita.

Karya sastra merupakan aktivitas karakter, yakni ketika seorang pengarang melukiskan watak dan pribadi tokoh yang akan ditampilkan atau dihadirkan dan digambarkan pada tokoh yang dikehendakinya (Fitriani, 2019: 20). Pada cerita rekaan atau novel perlu adanya teknik yang diterapkan oleh penulis dalam menggambarkan personalitas atau karakter yang dimiliki oleh tokoh yakni melalui penokohan. Penokohan berkaitan dengan pemilihan jenis watak tokoh dan bagaimana cara watak tersebut dilukiskan dalam suatu rangkaian cerita naratif. Pelukisan tokoh merupakan suatu teknik 
yang digunakan untuk menggambarkan personalitas tokoh. Nurgiyantoro (2010: 194) dalam bukunya menyebutkan bahwa teknik pelukisan tokoh menyaran pada pelukisan secara langsung dan pelukisan secara tidak langsung. Pelukisan tokoh langsung disebut dengan istilah teknik ekspositori atau analitik, sedangkan pelukisan secara tidak langsun disebut dengan istilah teknik dramatik. Teknik pelukisan tokoh yang digunakan oleh penulis dalam novel Kembara Rindu berupa teknik pelukisan tokoh gabungan yang meliputi pelukisan tokoh langsung (analitik) dan pelukisan tokoh tidak langsung (dramatik). Sepertihalnya yang dikatakan Nurhidayati (2018: 499) bahwa pelukisan tokoh secara gabungan ini dimaksudkan untuk memberikan gambaran yang lebih alamiah (hidup), rinci, menarik, spontan, dan mengejutkan terhadap pengukuhan, perubahan, dan harapan dari setiap pikiran, sikap, pandangan, dan keyakinan para tokoh.

Pelukisan tokoh secara langsung dan tidak langsung mempunyai kelebihan, kekurangan dan penggunaannya masing-masing yang berkaitan dengan selera pengarang dan kebutuhan penceritaan. Tidak ada seorang pengarang yang secara mutlak hanya mempergunakan salah satu teknik tanpa memanfaatkan teknik yang lain. Pada umumnya pengarang akan memilik cara campuran yakni dengan mempergunakan teknik langsung dan tidak langsung dalam suatu karya sastra. Hal demikian dapat memberikan keuntungan karena kelemahan dari masing-masing teknik dapat ditutup oleh kelebihan dari teknik lainnya (Nurgiyantoro, 2010: 192-195).

Teknik analitik merupakan pelukisan tokoh cerita yang dilakukan oleh pengarang dalam karyanya dengan cara memberikan deskripsi, uraian, atau penjelasan secara langsung. Tokoh cerita oleh pengarang dihadirkan ke hadapan pembaca dengan tidak berbelit-belit melainkan langsung disertakan deskripsi kediriannya yang dapat berupa sikap, sifat, watak, tingkah laku, atau bahkan juga ciri fisik tokoh tersebut (Nurgiyantoro, 2010: 195). Teknik analitik memiliki kelebihan yakni bersifat sederhana dan cenderung ekonomis. Karena deskripsi kedirian tokoh dihadiran secara langsung maka para pembaca akan dapat dengan mudah memahami kedirian dari tokoh tersebut dengan tepat dan sesuai dengan apa yang ingin dikisahkan oleh pengarang, sehingga dapat menghindarkan dari kemungkinan salah tafsir atau interpretasi oleh pembaca. Penggunaan teknik analitik dalam penciptaan karya selain memberikan kelebihan juga memiliki kekurangan yakni pembaca seolah-olah kurang diberikan kesempatan untuk dapat secara aktif memberikan tanggapan secara imajianatif terhadap tokoh cerita berdasarkan persepsi dan pemahamannya masing-masing terhadap sifat-sifat kemanusiaan yang ada dalam realitas kehidupannya. Hal tersebut dapat dikatakan sebagai pembodohan terhadap pembaca karena meredupkan daya aktif dan imajinatifnya. Selanjutnya teknik dramatik yakni teknik pelukisan tokoh yang dilakukan secara tidak langsung yakni pengarang membiarkan para tokoh cerita untuk dapat menhadirkan kediriannya melalui berbagai aktivitas yang dilakukan oleh tokoh baik berupa aktivitas verbal yakni ucapannya maupun aktivitas nonverbal yakni dengan tindakan atau tingkah lakunya dan melalui peristiwa yang terjadi (Nurgiyantoro, 2010: 199). Kelebihan penggunaan teknik dramatik ialah pembaca diberikan kesempatan untuk dapat aktif dalam menafsirkan kedirian tokoh dalam cerita, sehingga pembaca dapat melibatan diri secara aktif, kreatif, dan imajinatif karena dapat menginterpretasikannya sesuai dengan realitas kehidupan nyata. Adanya 
kebebasan pembaca untuk dapat menafsirkan kedirian tokoh dapat menjadi kelemahan dari teknik dramatik karena dapat memungkinkan adanya kesalahan tafsir dan juga dirasa kurang ekonomis dalam penggunaan kata karena dalam melukiskan kedirian tokoh memerlukan narasi yang panjang. Pada dasarnya baik teknik analitik maupun teknik dramatik dapat menjadi tenik yang tepat untuk mendeskripsikan kedirian tokoh akan tetapi akan mejadi lebih efektif apabila dipergunakan secara tepat dan sesuai dengan kebutuhan. Seperti halnya dipergunakan secara variatif yang bersifat saling melengkapi. Misalnya tekik analitik digunakan untuk mendeskripsikan hal-hal yang dirasa lebih tepat daripada menggunakan teknik dramatik atau untuk dapat lebih mengintensifkan pelukisan watak yang telah dilakukan dengan teknik dramatik (Nurgiyantoro, 2010: 198).

Peneliti tertarik untuk menelaah topik ini dikarenakan pada penelitian-penelitian sebelumnya dominan peneliti lain merujuk pada mengidentifikasi dan memetakan watak tokoh, sedangkan pada penelitian ini mengacu pada mengidentifikasi cara penulis dalam menggambarkan tokoh pada suatu karya novel yakni dengan teknik analitik dan dramatik. Manfaat yang dapat diperoleh setelah diadakannya penelitian ini ialah hasil dari penelitian ini dapat digunakan sebagai bahan referensi bagi pembaca yang kesulitan dalam menentukan watak tokoh dan teknik pelukisan tokoh yang digunakan oleh seorang penulis, dan dapat pula dijadikan sebagai alternatif bahan ajar pada siswa terkait unsur intrinsik baik cerpen maupun novel. Penelitian ini difokuskan untuk menelaah teknik pelukisan analitik dan dramatik yang digunakan oleh Habiburrahman El Shirazy dalam menggambarkan tokoh Ridho yang merupakan tokoh utama dalam Novel Kembara Rindu. Peneliti memilih novel Kembara Rindu sebagai bahan analisis dikarenakan novel Kembara Rindu merupakan salah satu novel Best Seller karya Novelis kenamaan di Indonesia yakni Habiburrahman El Shirazy. Pada novel ini menyuguhkan banyak peristiwa dan konflik yang sangatlah kompleks yang dihadapi oleh para tokoh khususnya tokoh utama Ridho. Oleh karena itu peneliti meyakini bahwa dalam novel Kembara Rindu akan banyak ditemukan data sebagaimana topik yang diteliti.

\section{METODE PENELITIAN}

Penelitian ini menggunakan jenis penelitian deskriptif kualitatif. Metode penelitian kualitatif menurut Bogdan dan Taylor merupakan suatu jenis penelitian yang menghasilkan data deskriptif kualitatif yang berupa simbol-simbol, baik tulisan maupun lisan yang merupakan hasil dari perilaku objek yang diamati atau hasil dokumentasi yang bersifat alamiah (dalam Prastowo, 2011: 22). Tujuan dari suatu penelitian deskriptif yakni untuk membuat suatu deskripsi, gambaran atau lukisan yang sistematis, faktual dan akuratnya fakta-fakta yang telah ditemukan, sifat-sifat dan hubungan antar fenomena yang diselidiki (Hudayat, 2007: 23). Hasil analisis pada penelitian ini berupa uraian deskriptif yang mendeskripsikan teknik analitik dan teknik dramatik yang digunakan untuk menggambarkan watak tokoh utama dalam novel Kembara Rindu karya Habiburrahman El Shirazy.

Pada penelitian deskriptif kualitatif data penelitian yang dikumpulkan berupa katakata, gambar, dan bukan angka-angka (Moleong, 2017: 11). Data yang dianalisis pada penelitian ini ialah kata-kata atau kalimat yang mendeskripsikan watak tokoh dengan 
teknik analitik dan teknik dramatik dalam novel Kembara Rindu Karya Habiburrahman El Shirazy. Sumber data dalam suatu penelitian merupakan subjek dari mana suatu data dapat diperoleh (Arikunto, 2006: 129). Menurut Moleong (2017: 11) data pada penelitian kualitatif berasal dari naskah wawancara, catatan lapangan, foto, videotape, dokumen pribadi, catatan atau memo, dan dokumen resmi lainnya. Berdasarkan pernyataan tersebut pada penelitian ini data penelitian diperoleh dari dokumen yakni teks novel yang berjudul Kembara Rindu karya Habiburrahman El Shirazy dengan jumlah 266 halaman, dan diterbikan oleh Republika Penerbit pada September 2019.

Teknik pengumpulan data merupakan cara yang akan dilakukan oleh seorang peneliti untuk dapat mengumpulkan data-data penelitian. Pada penelitian ini teknik pengumpulan data yang digunakan ialah teknik telaah dokumen. Menurut Pohan (2007:74). Teknik pengumpulan data telaah dokumen merupakan cara mengumpulkan informasi-informasi yang didapatkan dari suatu dokumen, yakni berupa peninggalan tertulis, arsip-arsip, akta, ijazah, rapor, peraturan perundang-undangan, buku harian, surat-surat pribadi, catatan biografi, dan lain-lain yang memiliki keterkaitan dengan masalah yang diteliti (dalam Prastowo, 2011:226). Teknik telaah dokumen dipilih karena sumber data yang dianalisis pada penelitian ini berupa dokumen yakni teks novel Kembara Rindu karya Habiburrahman El Shirazy. Menurut Arikunto teknik telaah dokumen ini tidaklah sulit karena jika ada suatu kekeliruan sumber datanya masih tetap dan tidak berubah sebab yang diamati bukanlah benda hidup melainkan benda mati.

Menurut Nasution (1992: 9) instrumen pengumpulan data kualitatif yakni peneliti yang merupakan key instrument (instrumen kunci) atau alat penelitian utama (dalam Prastowo, 2011: 43). Tugas seorang peneliti sebagai instrumen utama yakni mencari dan mengumpulkan data yang sesuai dengan rumusan masalah yang telah ditentukan. Oleh karena itu, peneliti sendiri yang akan mencari data yang berupa kalimat-kalimat yang menggambarkan watak tokoh utama dengan teknik analitik dan teknik dramatik dalam novel Kembara Rindu karya Habiburrahman El Shirazy. Peneliti sebagai instrumen utama memerlukan instrumen lainnya sebagai penunjang atau alat pembantu dalam mengumpulkan data yakni tabel pengumpulan data.

Proses pengumpulan data penelitian ini dilakukan melalui tahapan yakni: 1) membaca teks novel Kembara Rindu karya Habiburrahman El Shirazy secara menyeluruh; 2) melakukan pengamatan terhadap isi cerita pada bagian struktural; 3) menggaris bawahi sekaligus mengklasifikasikan data penelitian yang berupa kalimatkalimat yang merujuk pada topik yang diteliti yakni berkaitan dengan penggambaran watak tokoh utama dengan teknik analitik dan dramatik.

Teknik analisis data pada penelitian ini adalah dengan menggunakan metode Miles dan Huberman yang berupa tiga tahapan proses analisis yakni reduksi data, penyajian data, dan penarikan kesimpulan atau verifikasi. Miles dan Huberman (2007: 16) menyebutkan bahwa kegiatan analisis pada data kualitatif merupakan suatu proses analisis yang terdiri atas tiga alur kegiatan atau tahapan yang terjadi secara bersamaan, yakni tahapan reduksi data, penyajian data, dan tahapan penarikan kesimpulan atau verifikasi (dalam Prastowo, 2011: 241). 
Tahap reduksi data yakni suatu proses pemilihan dan memfokuskan pada penyederhanaan data yang telah muncul saat melakukan observasi terhadap sumber data. Pada tahap reduksi data penelitian yakni kalimat yang mengandung penggambaran watak tokuh utama dengan teknik analitik dan teknik dramatik akan diberikan kode untuk membuat kategori dan memilih serta memilah data manakah yang tidak diperlukan untuk kemudian dibuang. Selanjutnya data yang telah terkumpul dan dikategorikan disajikan menjadi suatu bentuk pola-pola. Tahapan ini disebut dengan tahap penyajian data yang bertujuan untuk mempermudah adanya penarikan kesimpulan dan agar pembaca dapat dengan mudah memahami data yang telah direduksi. Data penelitian ini disajikan dengan bentuk narasi dekriptif. Tahap yang terakhir yakni tahap penarikan kesimpulan atau verifikasi dilakukan untuk mengetahui apakah data yang telah direduksi dan disajikan telah sesuai dengan fokus penelitian. Dilakukannya verifikasi ialah untuk memastikan ulang apakah data yang didapat merupakan data jenuh dan ajeg.

Teknik pengujian kesahihan data yang digunakan dalam penelitian ini ialah teknik peningkatan ketekunan, yakni dengan membaca, mengurai, dan mengamati lebih dalam serta intensif pada novel Kembara Rindu karya Habiburrahman El Shirazy sebagai sumber data penelitian. Teknik ini dipilih berdasarkan metode penelitian yang digunakan dalam penelitian ini yakni dengan metode telaah dokumen, sehingga yang dilakukan oleh peneliti untuk menguji tingkat kesahihan data ialah dengan cara meningkatkan ketekunan dalam menelaah novel. Menurut Prastowo (2011: 268) teknik meningkatkan ketekunan dinilai mampu untuk meningkatkan kredibilitas atau keabsahan suatu data karena pada tahap ini peneliti dapat melakukan pengecekan kembali apakah ada kesalahan atau tidak. Penelitian ini juga menggunakan teknik diskusi dengan teman sejawat yang telah mumpuni atau menguasai terkait materi yang menjadi bahan penelitian. Teman sejawat ini dapat berasal dari teman kuliah dan dosen yang menguasai materi unsur intrinsik novel khususnya pada unsur penokohan.

\section{PEMBAHASAN}

Tokoh merupakan salah satu unsur intrinsik atau unsur pembangun yang terdapat dalam struktur suatu karya. Oleh karena itu, tokoh merupakan salah satu unsur yang penting bahkan wajib ada dalam suatu karya sastra khususnya novel. Melalui tokoh pengarang dapat mengembangkan alur cerita melalui rangkaian peristiwa yang dialami oleh seorang tokoh. Pengarang suatu karya sastra dalam melukiskan dan menghadirkan tokohnya dalam suatu karya menggunakan berbagai macam teknik pelukisan tokoh. Tujuannya ialah agar para pembaca dapat mengenali karakteristik para tokoh dan menangkap dengan jelas dan tepat cerita atau pun amanat yang dihadirkan oleh pengarang melalui tokoh-tokoh dalam karya sastranya. Pada setiap pengarang memiliki kecenderungan masing-masing dalam menggunakan teknik pelukisan tokoh untuk menggambarkan tokoh-tokoh karyanya. Habiburrahman El Shirazy pada novel Kembara Rindu dalam menghadirkan dan melukiskan tokoh-tokoh dengan menggunakan teknik analitik dan teknik dramatik. Pengguanaan kedua teknik tersebut untuk dapat menantisipasi kekurangan atau kelemahan dari masing-masing teknik tersebut sehingga dapat saling melengkapi. Berikut merupakan deskripsi teknik analitik dan dramatik dalam melukiskan tokoh utama pada novel Kembara Rindu Karya Habiburrahman El Shirazy. 


\section{Teknik Analitik.}

Teknik analitik merupakan teknik pelukisan tokoh yang mana pengarang secara langsung memberikan pemaparan terkait watak atau karakter dari suatu tokoh, seperti halnya tokoh tersebut disebutkan pengarang sebagai tokoh yang keras hati, keras kepala, penyayang dan sebagainya (Zulfahnur, 2007: 6.30). Teknik pelukisan analitik memiliki ciri bahwa pelukisan gambaran seorang tokoh dengan cara tersurat yang mana dipaparkan secara langsung dalam kalimat tanpa berbelit-belit dan tidak memerlukan interpretasi mendalam. Pemaparan gambaran tokoh dapat berupa sikap, sifat, watak, tingkah laku, atau bahkan dari ciri fisiknya yang dideskripsikan secara langsung. Teknik Analitik yang digunakan Habiburrahman El Shirazy untuk menggambarkan karakteristik tokoh dalam novel Kembara Rindu sebagai berikut :

Teknik analitik atau pelukisan tokoh secara langsung dapat melalui pendeskripsian secara langsung oleh penulis dengan misalnya dengan mendeskripsikan secara langsung ciri fisik yang menunjukkan kedirian dari tokoh tersebut.

(1) "Sebagian besar penduduk desa memang mengenal dengan baik santri berwajah ramah itu." (Shirazy, 2019: 20).

Kutipan data (1) di atas menunjukkan bahwa tokoh utama Ridho merupakan seorang santri yang memiliki sifat ramah yang digambarkan secara langsung oleh penulis melalui ciri fisik dari tokoh yakni memiliki ciri fisik berwajah ramah. Data temuan tersebut juga sebagai penguat dari kalimat sebelumnya yakni "Khadim (asisten) kepercayaan Kyai Nawir itu melaju pelan melewati jalan desa . Sepanjang jalan hampir semua orang yang ia kenal disapanya dengan ramah." Bahwa tokoh utama Ridho di sepanjang jalan desa yang ia lewati, hampir semua orang yang ia kenal ia sapa dengan ramah. Pada data tersebut menunjukkan bahwa penulis menggunakan teknik pelukisan analitik pada diksi santri berwajah ramah yang menunjuukan bahwa penulis mendeskripsikan tokoh utama Ridho secara langsung yakni sebagai orang yang ramah dilihat dari ciri fisiknya yang berwajah ramah, kemudian oleh penulis diintensiskan dengan penggunaan teknik dramatik pada data Sepanjang jalan hampir semua orang yang ia kenal disapanya dengan ramah. Penjelasan sebelumnya sesuai dengan pernyataan Nurgiyantoro (2010: 198) bahwa teknik analitis dapat menjadi cukup efektif jika dipergunakan secara tepat dan sesuai dengan kebutuhan, misalnya dipergunakan secara variatif yang bersifat saling melengkapi dengan teknik dramatik pun untuk mengintensifkan pelukisan watak yang telah dilakukan dengan teknik analitik. Maka, penulis ingin menunjukkan secara lebih jelas dan gamblang bahwa tokoh utama Ridho merupakan tokoh yang ramah melalui ciri fisiknya yang disampaikan secara langsung dan kemudian diintensifkan kembali dengan mendeskripsikan secara tidak langsung yang menunjukkan bahwa tokoh utama Ridho melalui perilakunya merupakan seorang yang ramah.

(2)"Ridho menyeruput tehnya dengan kepala menunduk. Selama ini ia tidak berani memandang langsung wajah Kyai Nawir dan keluarganya sebagai bentuk penghormatannya. Demikian juga pada Diana. Menghormati anak guru adalah bagian dari menghormati guru." (Shirazy, 2019: 81)

Berdasarkan kutipan data (2) di atas penulis bermaksud mendeskripsikan secara langsung kedirian tokoh utama Ridho melalui kalimat "Selama ini ia tidak berani memandang langsung wajah Kyai Nawir dan keluarganya sebagai bentuk penghormatannya “. Melalui diksi tersebut menunjukkan bahwa tokoh Ridho merupakan 
seorang yang sopan dan selalu menjaga etika dihadapan baik guru maupun anak dari gurunya dengan cara menundukkan pandang sebagai bentuk menghormati.

(3)"Ridho mengenang perjalanannya menjadi khadim. Begitu diterima, ia menerima apa pun yang diminta Kyai Nawir dan keluarganya. Setengah tahun pertama lebih bersih-bersih dan ikut menjadi pasukan Cak Rosyid mengurus dan menjaga ternak ikan. Bukan berarti tugas bersih-bersih hilang, mengurus ikan itu tugas tambahan." (Shirazy, 2019: 70)

Berdasarkan kutipan data di atas penulis menggambarkan tokoh Ridho sebagai seorang yang pekerja keras yang di gambarkan secara langsung oleh penulis bahwa Ridho merupakan seorang tokoh yang bertanggung jawab atas setiap amanah yang diberikan kepadanya.

\section{Teknik Dramatik.}

Teknik dramatik merupakan penggambaran perwatakan yang tidak diceritakan secara langsung, melainkan melalui, pemilihan nama tokoh, penggambaran fisik atau postur tubuh, cara berpakaian, tingkah laku terhadap tokoh-tokoh lain, lingkungannya, dan dialog tokoh yang bersangkutan, serta interaksinya dengan tokoh-tokoh lainnya (Zulfahnur, 2007: 6.30). Menurut Nurgiyantoro (2010: 198) memaparkan bahwa dalam teknik pelukisan dramatik pengarang tidak mendeskripsikan secara eksplisit terkait sifat, sikap, dan tingkah laku tokoh melainkan membiarkan para tokoh cerita untuk dapat menunjukkan kediriannya sendiri melalui berbagai aktivitas yang dilakukan, baik secara verbal melalui kata atau ucapan maupun nonverbal melalui tindakan atau tingkah laku, dan melalui setiap peristiwa yang terjadi. Berdasarkan pernyataan tersebut dapat disimpulkan bahwa ciri dari teknik pelukisan dramatik ialah penggambaran watak atau pun personalitas tokoh tidak disampaikan secara eksplisit atau langsung melainkan dengan cara tersurat dan memerluka pemahaman dan interpretasi untuk dapat mengetahui kedirian dari tokoh tersebut. Teknik dramatik yang digunakan oleh Habiburrahman El Shirazy dalam menghadirkan dan menggambarkan karakteristik dari tokoh utama Ridho ialah sebagai berikut.

(4) "Kalau Udo Ridho sudah membaca apakah ia mau pulang ? Sebab ia tahu persis, saat terakhir Udo Ridho pulang dan kembali lagi ke pesantren, lelaki itu telah dipesan oleh Kakek Jirun agar tidak pulang sebelum disuruh kyainya pulang. Dan ia tahu persis Udo Ridho adalah anak yang sangat patuh pada pesan Kakek Jirun, juga sangat patuh pada guru-gurunya." (Shirazy, 2019: 7)

Kutipan data (4) menunjukkan bahwa tokoh utama Ridho digambarkan atau dilukiskan sebagai seorang anak yang patuh terhadap Kakeknya dan juga gurunya. Penggambaran tokoh utama Ridho sebagai anak yang patuh dihadirkan atau disampaikan oleh penulis secara tidak langsung melalui pemikiran dari tokoh lain yakni adik sepupu dari tokoh Ridho yang bernama Syifa. Pada kutipan tersebut dikisahkan bahwa tokoh Syifa sangat mengetahui bahwa kakak sepupunya merupakan anak yang sangat patuh dengan orang tua karena ia yatim piatu maka ia sangat patuh dengan Kakek Jirun dan juga gurunya. Oleh karena itu Syifa ragu apakah Ridho akan pulang kerumah sebelum disuruh Kyainya pulang, karena sebelumnya telah dipesan atau dititah oleh Kakek Jirun untuk tidak pulang sampai disuruh oleh Kyainya untuk pulang. 
(5) "Abah mengatakan, ia sangat bangga punya santri seperti Ridho yang berani menjaga marwah Kyainya.”(Shirazy, 2019: 140)

Data (5) di atas menunjukkan bahwa Ridho digambarkan memiliki watak yang pemberani. Penggambaran watak tersebut dihadirkan penulis melalui ucapan tokoh lainnya. Pada bagian ini Ridho digambarkan sebagai sosok yang berani dalam membela marwah Kyainya.

(6) "Saya ikut dawuh Gus Najib saja. Jawab Ridho dengan menunduk “ (Shirazy, 2019: 24)

Berdasarkan kutipan data di atas menunjukkan sosok Ridho sebagai tokoh yang patuh atau penurut, yang digambarkan atau dilukiskan oleh penulis melalui ucapan dari tokoh utama Ridho yakni "Saya ikut dawuh Gus Najib" kata dawuh dapat diartikan sebagai perintah. Jadi Ridho akan menuruti apa yang menjadi perintah dari Gus Najib.

(7) "Atau kalau mau, nanti saat saya pulang, silakan saya dicegat di jalan dekat lapangan sana, saya akan hadapi! Kita buktikan siapa yang hidup dan mati! Saya tidak rela sedikitpun Kyai saya dilecehkan, apalagi secara terangterangan" (Shirazy, 2019: 140).

Berdasarkan data di atas penulis dalam menunjukkan bahwa tokoh Ridho merupakan sosok yang pemberani, yakni melalui perkatannya dalam merespon tindakan dari dua preman yang kurang ajar dan semena-mena terhadap Kyainya yang sangat ia hormati. Bahkan ia siap bertanding melawan preman tersebut bahkan rela mati untuk menjaga marwah atau nama baik dari Kyainya.

(8) "Ada hal penting yang harus ia rampungkan, terutama terkait beberapa amanah. Ia sudah menemui Cak Rosyid dan menjelaskan semuanya. Seagala urusan dan amanahnya terkait kolam ikan dan pesantren yatim ia serahkan kepada Cak Rosyid sesuai arahan Kyai Nawir. Amanhnya di TPA Al Barokah di kampong sebelah selatan pesantren ia serahkan kepada Yunus. Amanahnya sebagai sekretaris Dewan Asatidz Pembina Pramuka Pesantren ia serahkan kepada Ustadz Jumhurudin untuk dimusyawarahkan penggantinya" (Shirazy, 2019: 52)

Berdasarkan data di atas penulis menggambarkan tokoh utama Ridho sebagai seorang yang sangat memegang amanah, hal tersebut dimunculkan oleh penulis melalui serangkain hal yang dilakukan oleh Ridho. Penggambaran di atas tidak secara langsung oleh penulis melainkan melalui rangkaian amanah yang akan dirampungkan dan telah disebutkan oleh penulis.

\section{SIMPULAN}

Berdasarkan hasil analisis dapat diambil beberapa simpulan sebagai berikut, yakni : 1) pada novel Kembara Rindu Habiburrahman El Shirazy melukiskan watak tokoh dengan menggunakan teknik analitik dan teknik dramatik, penggunaan kedua teknik dalam novel Kembara Rindu merupakan bentuk kecerdasan dari penulis untuk dapat menyiasati kekurangan dari salah satu teknik tersebut, sehingga kelebihan dari tiap teknik dapat menutupi kekurangan tersebut; 2) berdasarkan analisis ditemukan bahwa teknik dramatik merupakan teknik yang dominan digunakan dalam menghadirkan dan menggambarkan watak tokoh dalam suatu cerita ; 3) Berdasarkan hasil analisis ditemukan bahwa pada temuan data yang menggunakan teknik analitik yakni dilukiskan berdasarkan 
ciri fisik dari tokoh, sedangkan data dengan teknik dramatik dilukiskan berdasarkan pemikiran tokoh lain, tingkah laku tokoh, pemikiran tokoh, ucapan tokoh, dan ucapan tokoh lain.

Pengggunaan teknik analitik dan dramatik dalam novel Kembara Rindu merupakan bentuk kecerdasan dari penulis yakni Habiburrahman El Shirazy. Dikatakan demikian karena pada dasarnya setiap teknik pelukisan tokoh memiliki kelebihan dan kelemahan masing-masing, sehingga dengan digunakannya variasi teknik dalam karya maka diantara teknik pelukisan tokoh tersebut akan dapat saling melengkapi dan saling mengisi diantara teknik tersebut. Pemilihan teknik dramatik yang mendominasi penggambaran tokoh menunjukkan bahwa penulis bermaksud mendorong para pembaca untuk dapat secara aktif, kreatif, dan imajinatif untuk dapat memahami kedirian atau personalitas tokoh dalam novel dengan menggunakan daya interpretasinya masingmasing.

\section{REFERENSI}

Arikunto, S. (2006). Prosedur Penelitian Suatu Pendekatan Praktik. Jakarta: PT Rineka Cipta.

Buce Bungki, C. S. (2018). TEKNIK PELUKISAN TOKOH DALAM NOVEL HUJAN BULAN JUNI. Jurnal Pendidikan dan Pembelajaran Khatulistiwa, 3-4.

Fitriani, H. (2019). Analisis Penokohan Tokoh Aninun dalam Novel Habibi dan Ainun karya Baharudin Jusuf Habibi. Seulas Pinang: Jurnal Pendidikan Bahasa dan Sastra, 17-22.

Hudayat, A. Y. (2007). Metode Penelitian Sastra. Bandung: Universitas Padjajaran. Minderop, A. (2005). Metode Karakterisasi Fiksi. Jakarta: Yayasan Pustaka Obor Indonesia.

Moleong, L. J. (2017). Metodologi Penelitian Kualitatif. Bandung: PT Remaja Rosdakarya Offset.

Nurgiyantoro, B. (2010). Teori Pengkajian Fiksi. Yogyakarta: Gadjah Mada Press. Nurhidayati, N. (2018). Pelukisan Tokoh dan Penokohan dalam Karya Sastra. Prosiding Konferensi Nasional Bahasa Arab, 493-506.

Prastowo, A. (2011). Metode Penelitian Kualitatif dalam Perspektif Rancangan Penelitian. Jogjakarta: Ar-Ruzz Media.

Shella, I. H. (2020). TEKNIK PELUKISAN TOKOH DALAM NOVEL BULAN KERTAS. Jurnal Metamorfosa, 15-16.

Shirazy, H. E. (2019). Kembara Rindu. Jakarta: Rineka Penerbit.

Siswanto, W. (2013). Pengantar Teori Sastra. Yogyakarta: Aditya Media Publishing. 
Suprihadi. (2009). Trik Termudah Menguasai Bahasa Indonesia. Surabaya: Mitra Jaya. Tarigan, H. G. (2008). Menulis Sebagai Suatu Keterampilan Berbahasa. Bandung: Penerbit Angkasa Bandung.

Zulfahnur. (2007). Teori Sastra Indonesia. Jakarta: Universitas Terbuka. 